\title{
EPIYA motif patterns among Cuban Helicobacter pylori CagA positive strains
}

\author{
Lino E. Torres ${ }^{1}$, Lidice González¹, Karelia Melián², Jordis Alonso², Arlenis Moreno, \\ Mayrín Hernández¹, Orlando Reyes ${ }^{1}$, Ludisleydis Bermúdez¹, Javier Campos³ \\ Guillermo Pérez-Pérez ${ }^{4}$, Boris L. Rodríguez ${ }^{1}$ \\ 1 Department of Research and Development, Division of Production and Development of Equipments and \\ Diagnostics, National Centre for Scientific Research, Ciudad de La Habana, Cuba \\ 2 Department of Gastroenterology, Medical and Surgery Research Centre (CIMEQ), Ciudad de La Habana, Cuba \\ ${ }^{3}$ Department of Molecular Biology, Biotechnology Division, National Centre for Scientific Research, Ciudad de La \\ ${ }^{4}$ Departments of Medicine and Microbiology, New York University, School of Medicine, USA
} Habana, Cuba

Introduction. It is known that polymorphisms in C-terminal region of CagA influence gastric disease development on Helicobacter pylori infection. Additionally, the geographic distribution of these polymorphisms has been associated with the appearance of more severe gastroduodenal pathologies.

Objective. To determine the CagA phosphorylation motifs pattern (EPIYA pattern) in Cuban H. pylori isolates, and to study its association with patient's pathologies.

Materials and methods. DNAs from $95 \mathrm{H}$. pylori cagA-positive strains were used to amplify the 3' variable region of cagA gene by PCR using two different strategies. Additionally, new primers were designed to identify either Western or Eastern CagA EPIYA motif type by PCR. To confirm the PCR results, PCR products from 14 representative isolates were purified and sequenced

Results. The distribution of the EPIYA motif found was: $2 \mathrm{AB}(2.1 \%), 1 \mathrm{AC}(1.1 \%), 1 \mathrm{BC}(1.1 \%)$, 70 ABC (73.6 \%), 19 ABCC (20\%), and 2 ABCCC (2.1\%). Sequencing analysis confirmed the PCR classification in the 14 studied strains and showed three strains with unusual nucleotide sequences, not reported before. Distribution of the EPIYA-ABC pattern was equivalent in all pathologies $(78.9 \%$ in gastric ulcer, $72.5 \%$ in duodenal ulcer and $72.2 \%$ in non-ulcer dyspepsia).

Conclusion. The PCR results using the new primers confirmed that all studied strains carried the Western CagA type. No specific EPIYA motif was associated with peptic ulcer. This is the first report that shows EPIYA motif distribution in $H$. pylori isolates from the Caribbean region.

Key words: Helicobacter pylori, gastric neoplasms, virulence factors, Cuba.

Patrón de los motivos EPIYA de cepas cubanas de Helicobacter pylori positivas para CagA

Introducción. Se sabe que el polimorfismo en la región C-terminal de la citotoxina asociada al gen A (CagA) influye en el desarrollo de la enfermedad gástrica durante la infección por Helicobacter pylori. Objetivo. Determinar el número y el tipo de patrones de fosforilación de CagA (patrón EPIYA) en aislamientos cubanos de $H$. pylori, y estudiar su asociación con las enfermedades gástricas.

Materiales y métodos. Se empleó el ADN de 95 cepas de $H$. pylori positivas para CagA, para amplificar la región 3' variable del gen cagA por PCR, mediante el empleo de diferentes estrategias. Además, se diseñaron nuevos cebadores para clasificar por PCR los aislamientos según el tipo de CagA, occidental o del este asiático. Los productos de PCR obtenidos de 14 aislamientos representativos se purificaron y secuenciaron para confirmar los resultados de la PCR.

Resultados. La distribución de los patrones EPIYA encontrada, fue: 2 AB (2,1\%), 1 AC (1,1\%), 1 BC (1,1\%), 70 ABC (73,6 \%), 19 ABCC (20\%), y 2 ABCCC (2,1\%). El análisis de la secuenciación confirmó las clasificaciones hechas por PCR en las 14 cepas estudiadas y demostró tres cepas con secuencias únicas de nucleótídos, no reportadas anteriormente. La distribución del patrón EPIYA-ABC

\footnotetext{
Author contributions:

L. E. Torres and B. L. Rodríguez contributed equally to this work.

L. E. Torres, L. González, J. Campos and B. L. Rodríguez designed the research.

L. González, L. E. Torres, O. Reyes, A. Moreno, M. Hernández, L. Bermúdez collected and processed the samples and performed the research.

K. Melián, J. Alonso performed the endoscopy and managed the patient data.

L. E. Torres, L. González, G. Pérez-Pérez and B. L. Rodríguez analyzed the data and wrote the paper.
} 
fue equivalente en todas las enfermedades encontradas: 78,9 \% en úlcera gástrica, 72,5 \% en úlcera duodenal y $72,2 \%$ en dispepsia no ulcerada.

Conclusión. La mayoría de los aislamientos cubanos presentaron las combinaciones de motivos EPIYA menos virulentas (ABC). Los resultados del empleo de los nuevos cebadores y el análisis de la secuenciación, confirmaron que todas las cepas estudiadas portaban el gen cagA de tipo occidental. Ninguno de los patrones específicos de EPIYA se asoció con úlcera péptica. Este es el primer reporte que muestra la distribución de los motivos EPIYA en los aislamientos de $H$. pylori de la región del Caribe.

Palabras clave: Helicobacter pylori, neoplasias gástricas, factores de virulencia, Cuba.

H. pylori strains producing the cytotoxin associated gene A protein (CagA) have been related with the development of severe gastroduodenal diseases, atrophic gastritis and gastric adenocarcinoma $(1,2)$. Gastric carcinoma (GC) is one of the leading causes of cancer-related deaths in many parts of the world (3). The CagA protein is delivered into the epithelial cells for a Type IV Secretion System(4) and it is phosphorylated by host kinases on the tyrosine phosphorylation motifs (TPMs) called EPIYA (GluPro-lle-Tyr-Ala), located in the carboxyl-terminal region $(5,6)$. Upon phosphorylation, CagA interacts with the phosphatase SHP-2 (7), activating the Erk MAP kinase cascade eliciting a cell-morphological transformation, which is characterized by a dramatic cytoskeletal rearrangements of epithelial cells $(1,8)$. Additionally, phosphorylated CagA can stimulate multiple motility-inducing signaling cascades such as the activation of cAbl (9) and Crkll cascades(10). Therefore, deregulation of SHP-2 by CagA plays an important role in gastric carcinoma development (1). On the other hand, CagA also disturbs cell functions in a tyrosine phosphorylation-independent manner, activating a nuclear factor that induces transcription of several inflammatory genes (11). Furthermore, CagA is also capable of activating NF- $\kappa \beta$, which in turn induces interleukin-8 expression(12) and more recently, it has been reported that this bacterial protein deregulate the $\beta$-catenin signaling (13).

CagA TPMs are classified as type A, B, C and D based on specificamino acid sequences surrounding the EPIYA motif (7). The $H$. pylori strains isolated from Western countries mainly consist of EPIYA-A, $B$, and a single or multiple repeat of $C$ segment, while East Asian strains (Eastern strains) mainly have a combination of EPIYA-A, B and D motifs

\section{Corresponding author:}

Boris Luis Rodríguez, Development and Research Department, Division of Equipments and Diagnostics, National Centre for Scientific Research, Avenida 25 and 158, Cubanacán, Playa, AP 6412, Ciudad de La Habana, Cuba.

Teléfono: (537) 208-0959; fax: (537) 208-7538

boris.rodriguez@cnic.edu.cu

Recibido: 26/05/11; aceptado:14/09/11
(7). SHP-2 binds both EPIYA-C and D motifs, but EPIYA-D exhibits greater SHP-2 binding activity and therefore a stronger ability to induce severe changes in epithelial cells $(7,14)$. Consequently, the predominant presence of strains carrying an EPIYA-ABD type has been associated with the higher $\mathrm{GC}$ rate in East Asia $(1,15,16)$. Furthermore, Western strains harboring multiple EPIYA-C motifs have been more frequently isolated from patients with gastric adenocarcinoma $(17,18)$. The above observations support the hypothesis that specific TPM patterns could determine the carcinogenic potential of $H$. pylori isolates, and partly explaining the geographic differences in GC incidence (1). In fact, very recently CagA have been recognized as the first bacterial oncoprotein which acts in mammalian cells (19) and its carcinogenic activity is modulated by specific TPM patterns (20). Therefore, accurate detection of the EPIYA pattern may become a useful prognostic tool for gastric malignancy due to $H$. pylori infection. Despite the relevance of TPM patterns in CagA protein as virulence markers, there are not reports about the EPIYA types among Cuban $H$. pylori isolates, or from strains isolated in the Caribbean region, despite that gastric cancer death rate varies significantly between countries in this region (21). In this disease, the highest mortality rates are exhibited by the Haitian males and Jamaican females with 25.1/100 000 and 11.6/100 000 , respectively, while 9.7 and 5.6/100 000 are the lowest rates in the area, reported for Cuban males and females, respectively (21,http://www. sld.cu/servicios/estadisticas/). Therefore, the aim of this work was to study the EPIYA motif pattern of CagA gene in $H$. pylori isolates from a Caribbean population.

\section{Materials and methods}

\section{Patients and $\mathrm{H}$. pylori isolates}

A total of 95 cagA positive $H$. pylori strains were isolated from antrum biopsies in a previous study involving 130 consecutive patients ( 77 male and 53 female) with a mean age of 49.1 (range 18 to 88) who underwent routine endoscopy due to dyspeptic 
complaints at CIMEQ Hospital, Havana, Cuba (22). Patients were classified in three groups (40 with duodenal ulcer, 19 with gastric ulcer, and 36 with non-ulcer dyspepsia) according to endoscopic and histological observations. H. pylori strains $\mathrm{J} 99$ and CCUG-17874 were used as reference strains, and kindly provided by Professor Francis Megraud from Pellegrin Hospital, Bordeaux, France and Professor Ann-Mary Svennerholm, Gothenburg University, Sweden, respectively. All the strains were cultured as previously described (22).

\section{DNA extraction and PCR amplification}

Genomic DNAs of the strains were extracted by CTAB method with phenol/chloroform and isopropanol precipitation as previously described (22). Purified DNAs were stored at $-20^{\circ} \mathrm{C}$ until use. PCR amplifications were carried out in a $25 \mu \mathrm{l}$ reaction mixture containing $2.5 \mu \mathrm{l}$ 10X PCR buffer, $0.2 \mathrm{mM}$ of each deoxynucleotide triphosphate, 0.6 $\mathrm{mM}$ sense and antisense primers, $4 \mathrm{mM}$ magnesium chloride, $1.25 \cup$ Taq DNA polymerase (CIGB, Cuba) and $100 \mathrm{ng}$ genomic DNA. The PCR had an initial step at $94^{\circ} \mathrm{C}$ for $1 \mathrm{~min}$, followed by 40 cycles at $94^{\circ} \mathrm{C}$ for $1 \mathrm{~min}, 60^{\circ} \mathrm{C}$ for $1 \mathrm{~min}$ and $72^{\circ} \mathrm{C}$ for $1 \mathrm{~min}$, and a final extension at $72^{\circ} \mathrm{C}$ for $5 \mathrm{~min}$, using a Master Cycler apparatus (Eppendorf, Germany). Several primers were used for subtyping cagA variable region (table 1). PCR products were separated on $1.6 \%$ agarose gel electrophoresis containing ethidium bromide. Images were digitalized using the Gene Genius system (Syngene, England).

\section{Sequence analysis of the $3^{\prime}$ region of cagA gene}

DNAs amplified with primers cag2 and cag4 (Table 1) from 14 representative strains of different EPIYA patterns were isolated by using the ADN-GFX'M purification kit (Amersham-Pharmacia, Germany) and sent for sequence analysis to Macrogen Inc., Korea. Sequencing reactions were performed for both DNA strands, and the ClustalW2 multiplesequence alignment software was used to analyse sequencing results.

\section{Specific subtyping of cagA gene into EPIYA-C or $D$}

Two new reverse primers were synthesized, cagAEpiC and cagA-EpiD (table 1), to differentiate EPIYA motifs $C$ and $D$ by PCR. These reverse primers were used with forward primer cag2 (Table 1 ) and were designed using cag $A$ gene sequences from Western and East Asian isolates published in Genbank Database and employing the Genrunner Software. Professor Guillermo Pérez-Pérez, from New York University, USA, kindly provided us with four DNAs from Eastern CagA isolates which were used as controls in our experiments.

\section{Accession numbers}

The nucleotide sequences of the cag $A$ variable region from $H$. pylori strains in this study have been published in the GenBank database under accession numbers EU443785 (strain Hpcnic35 ) and EU444054 to EU444066 (strains Hpcnic22. Hpcnic-47, Hpcnic-74, Hpcnic-8, Hpcnic-10, Hpcnic-14, Hpcnic-15, Hpcnic-16, Hpcnic-17, Hpcnic-27, Hpcnic-19, Hpcnic-28 and Hpcnic-3).

\section{Statistical analysis}

Differences between groups were tested by $\chi^{2}$ test. $P$ values $<0.05$ were considered to be significant. The Statistic software, version 8 for Windows, was used for statistical analysis.

Table 1. Primers used for characterization of CagA TPMs of Cuban Helicobacter pylori strains

\begin{tabular}{|c|c|c|c|c|}
\hline Primer & Sequence (5'-3') & $\begin{array}{l}\mathrm{AT}^{\dagger} \\
\left({ }^{\circ} \mathrm{C}\right)\end{array}$ & $\begin{array}{l}\text { Product Size } \\
\text { (bp) })^{\S}\end{array}$ & Reference \\
\hline cag2 & GGAACCCTAGTCGGTAATG & 50 & - & (23) \\
\hline cag4 & ATCTTTGAGCTTGTCTATCG & 50 & $\begin{array}{l}\text { Variable } \\
(400-750)\end{array}$ & (23) \\
\hline cagA-P1C & GTCCTGCTTTCTTTTTATTAACTTTAGC & 60 & 174 & (24) \\
\hline cagA-P2 CG & TTTAGCAACTTGAGCGTAAATGGG & 60 & 222 & (24) \\
\hline cagA-P3E & ATCAATTGTAGCGTAAATGGG & 60 & 378 & (24) \\
\hline cagEpi-C & AAAGGTCCGCCGAGATCA & 60 & 397 & This study \\
\hline cagEpi-D & GCCTGCTTGATTTGCCTCATC & 60 & 399 & This study \\
\hline
\end{tabular}

${ }^{\dagger}$ Annealing temperature in centigrades degree.

$\S$ The size corresponds to the cagA sequence for reference strain 26695, which exhibits the EPIYA-ABC pattern, and only the size showed with primer cagEpi-D was taken from the Eastern strain F-13. 


\section{Results}

\section{Determination of EPIYA pattern by PCR}

Detection of the EPIYA pattern was made first by PCR amplification of $3^{\prime}$ variable region of cagA gene, by using primers originally designed to detect cagA gene (primers cag2 and cag4, table $1)$. The strategy renders an amplicon of varying sizes according to the number of EPIYA motifs (24). These PCR reactions generated DNA fragments of 400 to $750 \mathrm{bp}$ that were visualized on agarose gel electrophoresis (figure 1). DNAs from the reference strains $\mathrm{J} 99$ and CCUG-17874 exhibited their expected sizes of the cagA gene fragment (figure 1). The appearance of a double band in the electrophoresis of PCR products may reveal the presence of a co-infection or microevolution of a single strain in a given patient. There were only three strains in which the presence of strains with more than one EPIYA pattern was confirmed (figure 1), and all of them carried a mixed BC-ABC EPIYA pattern. Although, the above PCR methods allow estimating the EPIYA pattern of $H$. pylori strains, the exact prediction of the EPIYA motifs of a given strain cannot be established. Therefore, the elegant PCR method from Argent et al, (25) was carried out to determine the exact EPIYA type and number in our isolates (data not shown). This methodology amplifies each EPIYA sequence in three different PCRs, using the forward primer cag2 with primers cagA-P1C, cagA-P2CG and cagA-P3 to amplify EPIYA motifs $A, B$ and $C$, respectively (table 1 ).

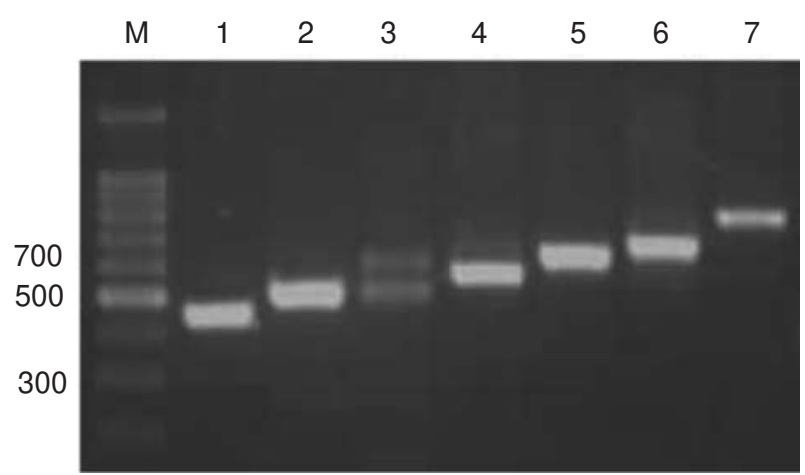

Figure 1. Electrophoretic analysis of PCR products of cagA variable region amplifications from Cuban Helicobacter pylori isolates. PCR were developed using primers cag2 and cag4. The shown results are the representative band sizes found among studied Cuban H. pylori strains. Lane 1: CCUG 17874 (449 bp, AB), Lane 2: J99 (500 bp, BC), Lane 3: Hpcnic-30 ( 500 and $554 \mathrm{bp}$, representative of the three BC-ABC detected patterns), Lane 4: Hpcnic-14 (554 bp, ABC), Lane 5: Hpcnic-27 (600 bp, ABC with an insertion of 22 aas), Lane 6: Hpcnic-19 (654 bp, ABCC) , Lane 7: Hpcnic-22 (754 bp, ABCCC), M: 100 bp DNA ladder (Promega,USA).
The EPIYA motifs in 95 Cuban H. pylori strains shown that most of isolates $(73.7 \%)$ carries three TPMs with a single copy of the EPIYA-C motif (table 2). Additionally, three of our strains had an EPIYA-C that differs from the normal size of this motif, and one of them also lacks most of its EPIYA-B segment (table 2). The nucleotide sequence of these three strains (Hpcnic-27, Hpcnic-35 and Hpcnic-47) were studied in detail by sequencing analysis (figure 2 ). Furthermore, nineteen $(20 \%)$ Cuban strains had the EPIYA-ABCC type and only two strains (2.1\%) had the ABCCC pattern (table 2).

\section{Subtyping of cagA gene by PCR}

Despite of the capacity of the above mentioned PCRs to determine the EPIYA pattern of $H$. pylori strains, none of them can distinguish between EPIYA-C and D motifs because designed primers to amplify the $C$ motif are unspecific, and also amplify EPIYA-D. Therefore, we designed two new reverse primers to be used with the forward primer cag2 (table 1), for the specific detection of the EPIYA-C and $D$ motifs. The new specific primer for TPM-C anneals to nucleotide positions 2928 to 2945, in cagA gene (HP0547) from the reference strain 26695. The specific primer for EPIYA-D anneals to nucleotide positions 2890 to 2910 of cagA gene (AB090073) from the Eastern strain F-13. The generated PCR-products by the new primers for EPIYA-C and D were visualized as bands of 397 and 399 bp on agarose gel electrophoresis, respectively (figure 3 , Panels $A$ and $B$, respectively). In the case of Western strains containing multiple $\mathrm{C}$-segments (figure 3, Panel C), there might be a 102-bp increment over the first C motif (397 bp band), resulting in a new 499-bp amplicon for CC type strains (figure 3, Panel C, line 2) and a third 602-bp amplicon for CCC type strains (figure 3, Panel C, line 3). From the 95 Cuban strains analyzed with primer cagAEpi-C (table 1), 93 carried the EPIYA-C motif and none of the 95 isolates rendered an amplicon when the cagAEpi-D primer was used. In contrast, the four DNAs from Eastern cagA isolates were positive with cagAEpi-D primer and negative with cagAEpi-C primer (figure 3). The two Cuban strains that lack the TPM- $C$ were also $C$ negative by the new specific primer to the EPIYA-C motif (data not shown) and one of them (Hpcnic-74) was confirmed by sequence analysis (figure 2).

\section{Sequencing analysis of the cagA gene variable region}

Nucleotide sequencing reactions were performed in the $3^{\prime}$ variable region of cagA gene from 14 
A

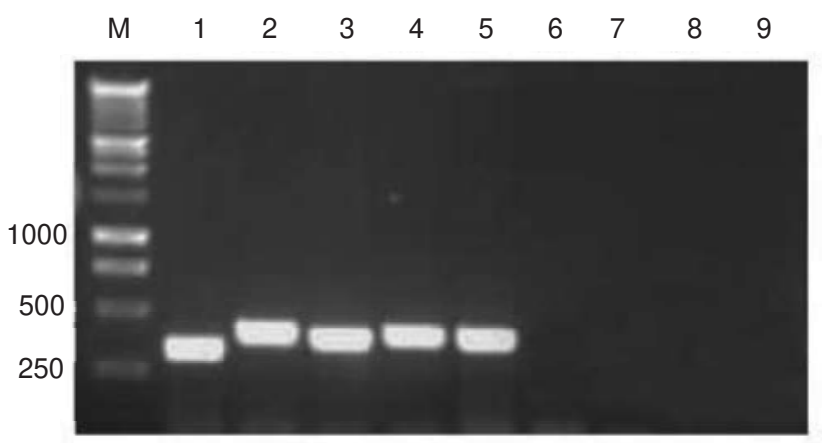

B

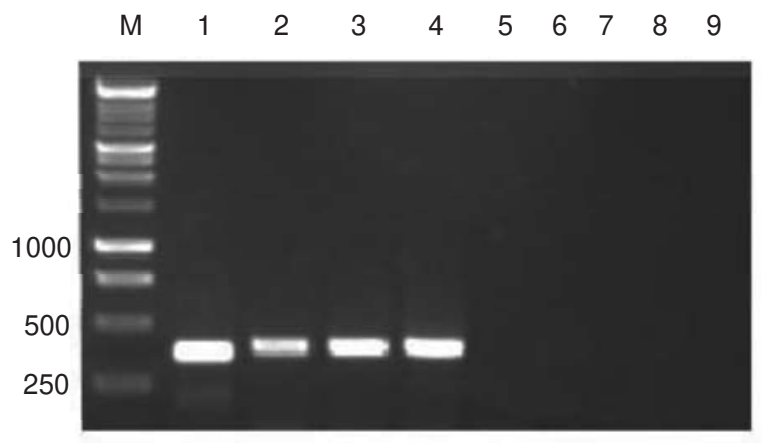

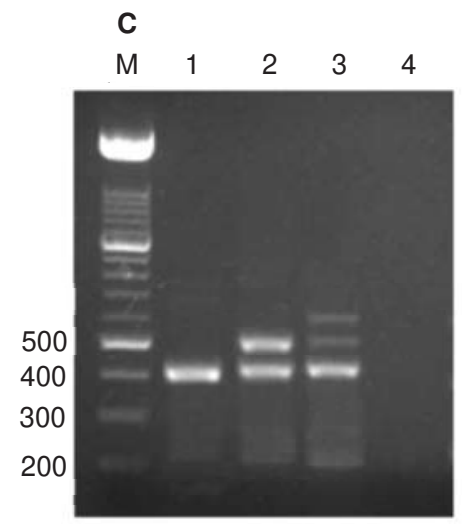

Figure 2. Alignment of deduced amino acid sequences of the $3^{\prime}$ cagA variable region from nine Cuban Helicobacter pylori strains. These sequences are representative of all the different detected TPM patterns. Normal EPIYA$A B$ (Hpcnic-74), EPIYA-AC with a deletion of 21 aa in the EPIYA-C motif of cagA gene (Hpcnic-35), Normal EPIYA-BC (Hpcnic-3), normal EPIYA-ABC (Hpcnic-14 and Hpcnic-17), EPIYA-ABC with a deletion of 15 aa just after the EPIYA-C motif (Hpcnic-47), EPIYA-ABC with an insertion of 22 aa between the second and third EPIYA repeats (Hpcnic-27), normal EPIYA-ABCC (Hpcnic-19) and normal EPIYA-ABCCC (Hpcnic-22).

Table 2. Prevalence of the EPIYA pattern among 95 Cuban Helicobacter pylori strains and relationship to clinical outcome.

\begin{tabular}{|c|c|c|c|c|}
\hline EPIYA type & $\begin{array}{c}\text { Strains } \\
\text { n (\%) }\end{array}$ & $\begin{array}{l}\text { Non-ulcer } \\
\text { dyspepsia }\end{array}$ & $\begin{array}{l}\text { Duodenal } \\
\text { ulcer }\end{array}$ & $\begin{array}{c}\text { Gastric } \\
\text { ulcer }\end{array}$ \\
\hline$\overline{A B}$ & $2(2.1)$ & 1 & 1 & - \\
\hline $\mathrm{AC}^{+}$ & 1 (1.1) & - & - & 1 \\
\hline $\mathrm{BC}$ & 1 (1.1) & 1 & - & - \\
\hline $\mathrm{ABC} \S$ & 70 (73.6) & 26 & 29 & 15 \\
\hline ABCC & $19 \quad(20)$ & 7 & 9 & 3 \\
\hline ABCCC & $2(2.1)$ & 1 & 1 & - \\
\hline Total & $95 \quad 36$ & 40 & 19 & \\
\hline
\end{tabular}

† Strain Hpcnic-35 carrying a deletion of 21 aa in the EPIYA-C motif of cagA gene.

$\S$ Two of the ABC strains showed specific mutations, strain Hpcnic-47 (from gastric ulcer patient) had a deletion of 15 aa just after the EPIYA-C motif and Hpcnic-27 (from non ulcer dyspepsia patient) had an insertion of 22 aa after the EPIYA-B motif.

representative strains using the cag2 and cag4 primers (table 1) to amplify this region. The PCR predictions perfectly matched the EPIYA pattern in the fourteen strains. In figure 2, we showed the variability found in the deduced peptide sequences of 9 studied strains. Three strains showing an EPIYA-C of different sizes in PCR analyses (table 2) were sequenced twice, in order to be sure of the results. The strain Hpcnic- 47 had a deletion of 15 aa just after the EPIYA-C motif (figure 2) and the strain Hpcnic-27 had an insertion of 22 aa between the second and third EPIYA repeats. Furthermore, the strain Hpcnic-35 showed almost full deletion of the EPIYA-B sequence and a 21 aa deletion of EPIYA-C motif, coding for an unusually short cagA variable region. These specific mutations in the EPIYA-C fragment had not been reported before in Database, and reflect the high intragenic recombination in the cag $A$ variable region.

The $95 \mathrm{H}$. pylori strains were isolated from 19 cases of gastric ulcer, 40 from duodenal ulcer and 36 from non-ulcer dyspepsia, and the EPIYA-ABC motifs were detected in $78.9 \%, 72.5 \%$ and 72.2 $\%$, respectively (Table 2 ). Thus, there was not a specific EPIYA motifs associated with peptic ulcer. Furthermore, no correlation was observed between 
Hpcnic- 74
Hpcnic- 35
Hpcnic-3
Hpcnic-47
Hpcnic- 14
Hpcnic-17
Hpcnic-27
Hpcnic- 19
Hpenic-22

Hpenic- 74

Hpcnic-35

Hpcnic- 3

Hpcnic- 47

Hpenic- 14

Hpenic-17

Hpcnic- 27

Hpenic-19

Hpcnic- 22

Hpenic- 74

Hpcnic- 35

Hpcnic- 3

Hpenic- 47

Hpcnic- 14

Hpcnic- 17

Hpcnic-27

Hpenic- 19

Hpcnic-22

Hpenic- 74

Hpcnic- 35

Hpcnic- 3

Hpcnic- 47

Hpcnic-14

Hpcnic-17

Hpcnic- 27

Hpcnic- 19

Hpcnic-22
NFSDIKKELNAKL-GNFNNNNNNGLKN-------EPIYAKVNKKKAGQAASLEEPIYAQV NFSDIKKELNEK-FKNFNNNNN-GLKNST-----EPIYAKVNKKKTGQVASPE------NFSDIKKELNAKLFGNFNNNNNNGLKNST---------------------EPIYTQV NFSDIKKELNAKLFGNFNNNNNNGLKNST-----EPIYAKVNKKKAGQAASPEEPIYAQV NFSDIKKELNEK-FKNFNNNNN-GLKNSG-----EPIYAKVNKKKAGQVASPEEPIYAQV NFSDIKKELNEK-FKNFNNNNS-GLKNGKDKGPEEPIYAQVNKKKTGQVASPEEPVYAQV NFSDIKKELNEK-FKNFNNNNN-GLKNG---G--EPIYAQVNKKKTGQVASPEEPIYTQV NFSDIKKELNAKLFGI FNNNNN-GLKNST-----EPIYAKVNKKKAGQAASPEEPIYAQV NFSDIKKELNAKLFGI FNNNNN-GLKNST-----EPIYAKVNKKKAGQAASPEEPIYAQV

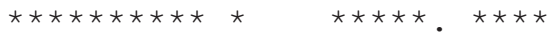

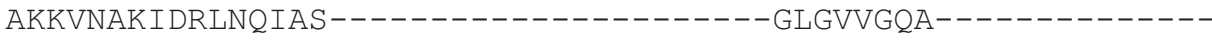

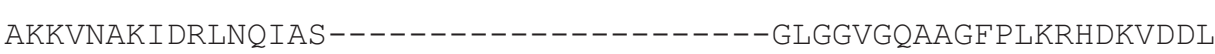
AKKVNAKIDQLNQAAS--------------------GFGGVGQA-GFPLKRHDKVDDL AKKVTQKIDQLNQAAS-------------------GFGGVGQA-GFPLKRHDKVDDL AKKVTKKIDQLNQAAT------------------SGLGGVGQA-GFPLKRHDKVEDL ARKVTQKIDQLNQAASGFGGVGQAGFPLKRHDKVDDLSKVGGVGQA-GFPLKRHDKVDDL AKKVNAKIDQLNQAAS--------------------GLGGVGQA-GFPLKRHDKVDDL AKKVNAKIDQLNQAAS--------------------GLGGVGQA-GFPLKRHDKVDDL

Figure 3. PCR method used to classify Helicobacter pylori cagA gene into Western or Eastern type. Panel A: Electrophoretic analysis of PCR products amplified with primers cag2 and the new primer cagAEpi-C (specific to amplify EPIYA-C motif). Lane 1: J99 strain. Lanes 2-5: Cuban cagA Western strains (Hpcnic-8, Hpcnic-10, Hpcnic-14, Hpcnic-17). Lanes 6-9: The four Eastern cagA isolates. Panel B: PCR products obtained with primers cag2 and the new primer cagAEpi-D (specific to amplify EPIYA-D motif). Lanes 1-4: The four Eastern strains. Lanes 5-9: Cuban cagA Western strains. Panel C: PCR products obtained with primers cag2 and the new primer cagAEpi-C. Lane 1: 26695 strain, Lane 2: Hpcnic-19, Lane 3: Hpcnic-22, Lane 4: Eastern cagA isolate (C-negative). M: [Panel A and B, 1 kb DNA ladder (Promega,USA) and Panel C, 100 bp DNA ladder (Roche, Germany)].

the type and number of the EPIYA motifs and any other gastroduodenal diseases (table 2).

\section{Discussion}

Characterization of the EPIYA motif types seems to be a better virulence marker than detection of $\operatorname{cag} A$ gene prevalence alone to predict the pathogenic potential of $H$. pylori (1). The prevalence of CagA protein and its corresponding gene in Cuban $H$. pylori strains has already been detected $(22,26)$. However, the EPIYA motif patterns of Cuban $H$. pylori isolates has never been investigated before. 
PCR methodology is simpler and cheaper than sequencing analysis to determine EPIYA combinations in $H$. pylori strains. There are several set of primers that hybridized into cagA gene around the $3^{\prime}$ variable region and also generates a single band (27). Thus PCR methodologies, the reported previously (27) and the developed with primers cag2 and cag4 (25) have the same usefulness. Also, both PCR strategies could detect the presence of strains with more than one EPIYA pattern in the same patient.

Most of analyzed Cuban $H$. pylori isolates (73.7\%) carries a cagA gene with the common EPIYA$A B C$ pattern (table 2), that resembles the CagA type reported in various Western populations from Europe, Africa and America $(17,18,28,29)$. The percentage of $A B C$ type strains in our case is slightly higher than those above mentioned, suggesting a possible lesser degree of virulence among Cuban CagA positive strains. Further studies, including H. pylori strains from representative areas of our country are required to confirm this tendency.

The prevalence of multiple EPIYA-C motif in Cuban strains, was very low. This isolates have been reported to induce in vitro higher levels of tyrosine phosphorylation, SHP-2 binding activity and morphological damage to cells. Thus, CagA protein with a greater number of EPIYA-C repeats is considered to be pathophysiologically more virulent and carcinogenic $(17,18,29)$. There are only a few studies in Latin-America that have reported EPIYA patterns of cagA-positive $H$. pylori isolates. Most of the strains from Latin-America also had the EPIYA-ABC pattern reported in this study. On the other hand, differences in the prevalence of strains with multiple EPIYA-C have been reported in Costa Rica 10/33 (30.3\%) (30), Peru 3/26 (11.5 $\%)(28)$ and Mexico 6/30 (20\%) (31). While, three different studies from Colombia reported more than $31 \%$ multiple C strains (32-34). It is important to mentioned that Costa Rica and Colombia have higher prevalence of gastric cancer than the other countries.

The newly designed primers (cagAEpi-C and cagAEpi-C) allow determining by PCR the EPIYA status of cagA positive $H$. pylori isolates. The results obtained let all Cuban strains to be classified according to the Western CagA status and provide evidence that is possible to classify $H$. pylori strains in Western or Eastern CagA types by a simple PCR method, without perform sequencing analysis. However, both primers should be validated using further Eastern and Western H. pylori isolates. As far as we know, there are only two similar methods published to discriminate the EPIYA-C and $D$ repeats using PCR $(35,36)$, but the designed primers and methodology here are different from those already published. Our PCR strategy could be use in combination with the previous ones, since it has been reported the usefulness of different set of primers in the amplification of polymorphic genes in $H$. pylori, especially in studies from different populations $(36,37)$.

The efficacy of PCR methods from this study was confirmed by sequencing analysis; we found a great correlation in the fourteen analyzed isolates between sequencing and $P C R$ results. Three isolates showed variation in the EPIYA-C motif, reinforcing that this region at cagA gene is highly polymorphic. Previous studies have reported differences in the response induced in gastric epithelial cells, depending on the number and type of EPIYA motif, being EPIYA-C the most relevant TPM (7). Moreover, it has been reported that heterogenicity in this variable region, such as lack of EPIYA-B motif (31) or changes in the multimerization sequence (10) could explain the diversity in the response induced in gastric epithelial cells by infection with $H$. pylori strains. Taking these observations into account, it would be very interesting to study how the polymorphism found in our isolates influences the biological activity of CagA.

In our study there was no significant difference between the number of EPIYA motifs in $\mathrm{H}$. pylori from patients with different disease. These findings are in agreement with several reports that only found association to gastric adenocarcinoma and not to ulcer diseases $(17,18)$. Unfortunately, we could not study a relationship of EPIYA-C repeats to precancerous lesions or GC, since we have no patients having those pathologies. This fact, must be influenced by the low gastric cancer death rate (6.9 / 100000 in 2009, http://www.sld.cu/servicios/ estadisticas/) in Cuban population. We hypothesize that the absence and relatively low percentage of $H$. pylori isolates carrying the more carcinogenic $D$ or multiple C EPIYA motifs could be the main factor that influences the low rate of GC in our country. The absence of East-Asian CagA type in our study was an expected result, since this type is almost restricted to East Asian patients (38-41). EPIYA-D motif represents the CagA genotype with the highest association to premalignant lesions and GC development in infected persons $(15,16)$. The small percentage of multiple EPIYA-C strains found 
here also indicates a lower risk for carcinogenicity among our isolates. In fact, studies from Costa Rica and Colombia showed higher percentages of multiple C isolates $(30,32-34)$ as mentioned above, particularly in populations having a gastric cancer death rate over 20 / 100000 (42); whereas Mexico, with a similar multiple $\mathrm{C}$ percentages as Cuba (31), have GC rates below 10 / 100000 (42). However, two other molecular-epidemiological studies have found that the number of EPIYA-C motif was essentially equal in areas showing divergent incidence of GC. In the first study, strains from Nashville, EUA (low GC zone) and Colombia (high GC zone), no differences in proportion of multiple C motifs was found, indicating that other factors may influence differences in gastric cancer rates in these regions (33). Similar results were reported by Sicinschi et al., who found that the distribution of strains with one, two or three EPIYA-C motifs was not significantly different in two areas from Colombia with different gastric cancer levels (34). Due to the small number of strains characterized in the previous reports and that both reports came from the same research group, new molecular-epidemiological studies are needed to determine whether geographic differences in premalignant lesions and GC levels are influenced by the number of EPIYA-C motifs carried by infecting $H$. pylori strains.

In conclusion, the EPIYA motif pattern of Cuban $\mathrm{H}$. pylori isolates is reported for the first time. All Cuban isolates characterized harbor the Western cagA gene type, with a predominant pattern of EPIYA$A B C$ and a relatively low incidence of multiple $C$ motifs among the strains. These results assume that Cuban $H$. pylori circulating strains could have low carcinogenic potential, a finding that requires further studies. The new specific primers designed in this study are capable of classifying H. pylori $\operatorname{cag} A$ positive strains into Western or Eastern type. Additionally, mutations not reported before were found in the EPIYA-C motif of the cagA gene.

\section{Conflicts of interest}

The authors have declared no conflicts of interest.

\section{Financing}

This work was supported by a grant from the National Center for Scientific Research, Havana, Cuba.

\section{References}

1. Hatakeyama M, Higashi H. Helicobacter pylori CagA: A new paradigm for bacterial carcinogenesis. Cancer Sci. 2005;96:835-43.
2. Wu AH, Crabtree JE, Bernstein L, Hawtin P, Cockburn M, Tseng CC, et al. Role of Helicobacter pylori CagA+ strains and risk of adenocarcinoma of the stomach and esophagus. Int J Cancer. 2003;103:815-21.

3. Jemal A, Bray F, Center MM, Ferlay J, Ward E, Forman D. Global cancer statistics. CA Cancer J Clin. 2011;61:69-90.

4. Backert S, Selbach M. Role of type IV secretion in Helicobacter pylori pathogenesis. Cell Microbiol. 2008;10:1573-81.

5. Covacci A, Censini S, Bugnoli M, Petracca R, Burroni D, Macchia G, et al. Molecular characterization of the 128-kDa immunodominant antigen of Helicobacter pylori associated with cytotoxicity and duodenal ulcer. Proc Natl Acad Sci USA. 1993;90:5791-5.

6. Stein M, Bagnoli F, Halenbeck R, Rappuoli R, Fantl WJ, Covacci A. C-Src/Lyn kinases activate Helicobacter pylori CagA through tyrosine phosphorylation of the EPIYA motifs. Mol Microbiol. 2002;43:971-80.

7. Higashi H, Tsutsumi R, Fujita A, Yamazaki S, Asaka M, Azuma T, et al. Biological activity of the Helicobacter pylori virulence factor CagA is determined by variation in the tyrosine phosphorylation sites. Proc Natl Acad Sci USA. 2002;99:14428-33.

8. Segal ED, Cha J, Lo J, Falkow S, Tompkins LS. Altered states: Involvement of phosphorylated CagA in the induction of host cellular growth changes by Helicobacter pylori. Proc Natl Acad Sci USA. 1999;96:14559-64.

9. Smith M, Hold L, Tahara E, El-Omar E. Cellular and molecular aspects of gastric cancer. World J Gastroenterol. 2006;21:2979-90.

10. Kurashima Y, Murata-Kamiya N, Kikuchi K, Higashi $H$, Azuma $\mathrm{T}$, Kondo $\mathrm{S}$, et al. Deregulation of beta-catenin signal by Helicobacter pylori CagA requires the CagAmultimerization sequence. Int J Cancer. 2008;122:823-31.

11. Yokoyama K, Higashi H, Ishikawa S, Fujii Y, Kondo S, Kato $\mathbf{H}$, et al. Functional antagonism between Helicobacter pylori CagA and vacuolating toxin VacA in control of the NFAT signaling pathway in gastric epithelial cells. Proc Natl Acad Sci USA. 2005;102:9661-6.

12. Brandt S, Kwok T, Hartig R, Konig W, Backert S. NF-kB activation and potentiation of proinflammatory responses by the Helicobacter pylori CagA protein. Proc Natl Acad Sci USA. 2005;102:9300-5.

13. Murata-Kamiya N, Kurashima Y, Teishikata Y, Yamahashi Y, Saito Y, Higashi $\mathbf{H}$, et al. Helicobacter pylori CagA interacts with $\mathrm{E}$-cadherin and deregulates the b-catenin signal that promotes intestinal transdifferentiation in gastric epithelial cells. Oncogene. 2007;26:4617-26.

14. Higashi $\mathbf{H}$, Tsutsumi R, Muto $\mathbf{S}$, Sugiyama $\mathbf{T}$, Azuma T, Asaka M, et al. SHP-2 tyrosine phosphatase as an intracellular target of Helicobacter pylori CagA protein. Science. 2002;295:683-6.

15. Yamaoka Y, Kodama T, Kashima K, Graham DY, Sepulveda AR. Variants of the 3' region of the cagA gene in Helicobacter pylori isolates from patients with different $H$. pylori-associated diseases. J Clin Microbiol. 1998;36:2258-63.

16. Azuma T, Yamakawa A, Yamazaki S, Fukuta K, Ohtani M, Ito $\mathrm{Y}$, et al. Correlation between variation of the $3^{\prime}$ region of 
the cagA gene in Helicobacter pylori and disease outcome in Japan. J Infect Dis. 2002;186:1621-30.

17. Argent RH, Kidd M, Owen RJ, Thomas RJ, Limb MC, Atherton JC. Determinants and consequences of different levels of CagA phosphorylation for clinical isolates of Helicobacter pylori. Gastroenterology. 2004;127:514-23.

18. Basso D, Zambon CF, Letley DP, Stranges A, Marchet A, Rhead JL, et al. Clinical relevance of Helicobacter pylori $\operatorname{cag} A$ and $\operatorname{vac} A$ gene polymorphisms. Gastroenterology. 2008;135:91-9.

19. Ohnishi N, Yuasa H, Tanaka S, Sawa H, Miura M, Matsui A, et al. Transgenic expression of Helicobacter pylori CagA induces gastrointestinal and hematopoietic neoplasms in mouse. Proc Natl Acad Sci USA. 2008;22:1003-8.

20. Miura M, Ohnishi N, Tanaka S, Yanagiya K, Hatakeyama M. Differential oncogenic potential of geographically distinct Helicobacter pylori CagA isoforms in mice. Int $\mathrm{J}$ Cancer. 2009;125:2497-504.

21. Phillips AA, Jacobson JS, Magai C, Consedine N, Horowicz-Mehler NC, Neugut Al. Cancer incidence and mortality in the Caribbean. Cancer Invest. 2007;25:476-83.

22. Torres LE, Melian K, Moreno A, Alonso J, Sabatier CA, Hernández $M$, et al. Prevalence of vacA, cagA and babA2 genes in Cuban Helicobacter pylori isolates. World J Gastroenterol. 2009;15:204-10.

23. Xu C, Li ZS, Tu ZX, Xu GM, Gong YF, Man XH. Distribution of cagG gene in Helicobacter pylori isolates from Chinese patients with different gastroduodenal diseases and its clinical and pathological significance. World J Gastroenterol. 2003;9:2258-60.

24. Rudi J, Kolb C, Maiwald M, Kuck D, Sieg A, Galle PR, et al. Diversity of Helicobacter pylori vacA and cagA genes and relationship to VacA and CagA protein expression, cytotoxin production, and associated diseases. J Clin Microbiol. 1998;36:944-8

25. Argent RH, Zhang $\mathbf{Y}$, Atherton JC. Simple method for determination of the number of Helicobacter pylori CagA variable-region EPIYA tyrosine phosphorylation motifs by PCR. J Clin Microbiol. 2005;43:791-5.

26. Valmaseda T, Gisbert JP, Paniagua M, Pajares JM. Helicobacter pylori CagA antibodies in various gastroduodenal diseases from 2 different populations. Med Clin (Barc). 2002;118:90-3.

27. Panayotopoulou EG, Sgouras DN, Papadakos K, Kalliaropoulos A, Papatheodoridis G, Mentis AF, et al. Strategy to characterize the number and type of repeating EPIYA phosphorylation motifs in the carboxyl terminus of CagA protein in Helicobacter pylori clinical isolates. J Clin Microbiol. 2007;45:488-95.

28. Devi SM, Ahmed I, Khan AA, Rahman SA, Alvi A, Sechi LA, et al. Genomes of Helicobacter pylori from native Peruvians suggest admixture of ancestral and modern lineages and reveal a western type cag-pathogenicity island. BMC Genomics. 2006;7:191.

29. Argent RH, Hale JL, El Oma EM, Atherton JC. Differences in Helicobacter pylori CagA tyrosine phosphorylation motif patterns between Western and East Asian strains, and influences on interleukin-8 secretion. J Med Microbiol. 2008;5:1062-7.

30. Occhialini A, Marais A, Urdaci M, Sierra R, Muñoz N, Covacci $\mathbf{A}$, et al. Composition and gene expression of the cag pathogenicity island in Helicobacter pylori strains isolated from gastric carcinoma and gastritis patients in Costa Rica. Infect Immun. 2001;69:1902-8.

31. Reyes-León A, Atherton JC, Argent RH, Puente JL, Torres J. Heterogeneity in the activity of Mexican Helicobacter pylori strains in gastric epithelial cells and its association with diversity in the cagA gene. Infect Immun. 2007;75:3445-54.

32 .Yamaoka Y, El-Zimaity H, Gutiérrez O, Figura N, Kim J, Kodama T, et al. Relationship between the cagA 3' repeat region of Helicobacter pylori, gastric histology, and susceptibility to low pH. Gastroenterology. 1999;117:342-9.

33. Schneider N, Krishna U, Romero-Gallo J, Israel DA, Piazuelo MB, Camargo MC, et al. Role of Helicobacterpylori CagA molecular variations in induction of host pPhenotypes with carcinogenic potential. J Infect Dis. 2009;199:1218-21.

34. Sicinschi LA, Correa P, Peek RM, Camargo MC, Piazuelo $\mathrm{MB}$, Romero-Gallo J, et al. CagA C-terminal variations in Helicobacter pylori strains from Colombian patients with gastric precancerous lesions. Clin Microbiol Infect. 2010;16:369-78.

35. An B, Lee G, Lim K, Moon BS, Kim JB. Identification of the repeated number of $C$ and $D$ regions of tyrosine phosphorylation motifs in Helicobacter pylori cagA using multiplex PCR. Microbiol Immunol. 2008;5:479-83.

36. Schmidt H, Andres S, Kaakoush N, Engstrand L, Eriksson L, Goh K, et al. The prevalence of the duodenal ulcer promoting gene (dupA) in Helicobacter pylori isolates varies by ethnic group and is not universally associated with disease development: A case-control study. Gut Pathog. 2009;1:5.

37. Yamaoka Y. Roles of the plasticity regions of Helicobacter pylori in gastroduodenal pathogenesis. J Med Microbiol. 2008;57:545-53

38. Azuma T, Yamakawa A, Yamazaki S, Ohtani M, Ito Y, Muramatsu A, et al. Distinct diversity of the cag pathogenicity island among Helicobacter pylori strains in Japan. J Clin Microbiol. 2004;42:2508-17.

39. Vilaichone RK, Mahachai V, Tumwasorn S, Wu JY, Graham DY, Yamaoka Y. Molecular epidemiology and outcome of Helicobacter pylori infection in Thailand: A cultural cross roads. Helicobacter. 2004;9:453-9.

40. Zhu YL, Zheng S, Du Q, Qian KD, Fang PC. Characterization of CagA variable region of Helicobacter pylori isolates from Chinese patients. World J Gastroenterol. 2005;11:880-4.

41. Choi KD, Kim N, Lee DH, Kim JM, Kim JS, Jung HC, et al. Analysis of the 3' variable region of the cagA gene of Helicobacter pylori isolated in Koreans. Dig Dis Sci. 2007;52:960-6.

42. Bosetti C, Malvezzi M, Chatenoud L, Negri E, Levi F, La Vecchia C. Trends in cancer mortality in the Americas, 1970-2000. Ann Oncol. 2005;16:489-511. 